\title{
REVIEW: Is the decline of soil microbial biomass in late winter coupled to changes in the physical state of cold soils?
}

Robert L. Jefferies a, N. Alan Walker b, Kate A. Edwards a, *, Jack Dainty a

a Department of Ecology and Evolutionary Biology, University of Toronto, 25 Willcocks St., Toronto, Ontario M5S 3B2 Canada

b Plant Membrane Biophysics Group, Department of Biophysics, School of Physics, University of New South Wales, Sydney NSW 2052, Australia

\begin{abstract}
During winter when the active layer of Arctic and alpine soils is below $0{ }^{\circ} \mathrm{C}$, soil microbes are alive but metabolizing slowly, presumably in contact with unfrozen water. This unfrozen water is at the same negative chemical potential as the ice. While both the hydrostatic and the osmotic components of the chemical potential will contribute to this negative value, we argue that the osmotic component (osmotic potential) is the significant contributor. Hence, the soil microorganisms need to be at least halotolerant and psychrotolerant to survive in seasonally frozen soils. The low osmotic potential of unfrozen soil water will lead to the withdrawal of cell water, unless balanced by accumulation of compatible solutes. Many microbes appear to survive this dehydration, since microbial biomass in some situations is high, and rising, in winter. In late winter however, before the soil temperature rises above zero, there can be a considerable decline in soil microbial biomass due to the loss of compatible solutes from viable cells or to cell rupture. This decline may be caused by changes in the physical state of the system, specifically by sudden fluxes of melt water down channels in frozen soil, rapidly raising the chemical potential. The dehydrated cells may be unable to accommodate a rapid rise in osmotic potential so that cell membranes rupture and cells lyse. The exhaustion of soluble substrates released from senescing plant and microbial tissues in autumn and winter may also limit microbial growth, while in addition the rising temperatures may terminate a winter bloom of psychrophiles. Climate change is predicted to cause a decline in plant production in these northern soils, due to summer drought and to an increase in freezethaw cycles. Both of these may be expected to reduce soil microbial biomass in late winter. After lysis of microbial cells this biomass provides nutrients for plant growth in early spring. These feedbacks, in turn, could affect herbivory and production at higher trophic levels.
\end{abstract}




\section{Introduction}

Studies during the last decade have established that at least at some alpine and Arctic sites, microbial biomass reaches a peak in late winter and then declines during the period when soil temperatures rise to 0 C (Brooks et al., 1998; Lipson et al., 2000; Edwards et al., 2006; Larsen et al., 2007). In addition, a number of indirect measures of microbial activity at that season, based on $\mathrm{CO} 2$ fluxes and/or microbial nitrogen pools, are broadly consistent with such changes in microbial biomass (Brooks et al., 1998; Fahnestock et al.,1998). These and other authors have attributed the decline in biomass at the winterspring transition to a variety of causes, including the low level of soluble organic nutrients and the rupture of cell membranes by freeze-thaw cycles.

In this paper, we examine the decline in relation to the physical state of frozen soils, specifically changes in the hydraulic and osmotic environments, and how these physical changes during thaw may reduce the biomass of microbes. In order to discuss this topic fully, it is necessary to give an account of the physical changes that occur in organic cold soils from freeze-up to melt, as some important aspects of these changes have not been widely discussed. Here we discuss largely the situation in wet Arctic soils, drawing from four years of observations in Carex aquatilis e dominated wet meadows near Churchill, Manitoba, Canada (Edwards, unpublished observations). However, bearing in mind that the phenomenon of spring microbial decline is also seen in drier soils and in Alpine sites we feel that this discussion is broadly relevant to cold organic soils.

\section{Characteristics of organic wetland soils in high latitudes}

The widespread presence of organic soils in Arctic and sub-Arctic wetlands reflects the low rates of decomposition and often the poor drainage associated with perennially frozen soils (permafrost)characteristic of low-lying gently sloping landscapes (Slaughter and Kane, 1979; Quinton and Marsh, 1999; Carey and Woo, 2001). The porosity of these organic soils in the active layer is often large (up to $80 \%$ by volume) and individual pores may be larger than $1 \mathrm{~mm}$ in diameter (Luxmoore, 1981). The hydraulic mean radius of the pores declines rapidly with depth as a result of compression of organic material (Quinton et al., 2000; Carey and Woo, 2001). Only those pores that are interconnected contribute to the flow of water through the peat, so that not all pores conduct water. As discussed later, rapid movement of snow-and-ice melt water in surface peats (active layer) at the end of winter may lead to abrupt changes in the physical state of these soils that microorganisms must accommodate if they are to survive (Dunn and Phillips, 1991; Carey et al., 2007). Overall, the hydraulic conductivity in saturated organic soils is low (Quinton et al., 2000; Carey and Woo, 2001; Carey and Quinton, 2005) and of course it will be lower still when they are frozen. Although we discuss wet organic soils in general here, there is of course great variation between different Arctic wetland types, in important variables such as hydrology and snow depth, $\mathrm{pH}$ and redox chemistry, slope, and vegetation (Hinzman et al., 1996; Carey and Pomeroy, 2009). Substantial variation also exists at the microsite scale, which is relevant to understanding the environment experienced by microorganisms. During the thaw period the tundra 
landscape consists of a patchwork of areas that can vary considerably in terms of progression of thaw. Inter-annual variation also adds to the complexity of these systems, with snow accumulation, spatial patterns of water movement, and active layer development varying year to year.

\section{The freezing process}

At the onset of the freezing process in saturated peaty soils in autumn, a thin layer of frozen water overlies unfrozen soil, and a temperature gradient is established between the sub-zero air and the unfrozen soil. Latent heat is conducted away from the soil along this gradient, and the surface layer of soil freezes downwards. The water in the soil freezes progressively as its temperature falls over a range of values below zero (i.e. the soil water does not have a single definite freezing point). Three factors depress the freezing point of water in soils below $0^{\circ} \mathrm{C}$ :

\subsection{The Gibbse-Thomson effect}

A small radius of curvature on a convex ice surface raises its chemical potential, favouring the liquid state over the solid state in small (nm radius) hydrophilic pores. This depresses the freezing point of water by an amount that depends on the pore radius. This is relevant for water in nanometre pores, so not directly relevant to micrometre-sized organisms.

\subsection{Pre-melting}

The presence of unfrozen films of water on ice surfaces, both facing other solids and facing water vapour: Proposed by Faraday, these films are at a low chemical potential (i.e. in equilibrium with the ice) because they are under tension, a negative hydrostatic pressure generated by the repulsion between their surfaces (Dash, 1989; Rempel et al., 2004). This negative pressure is just that required to bring the water film into equilibrium with the ice. Its value can be calculated from equilibrium thermodynamics. The thickness of these films, which falls with temperature, is only of the order of a nanometre. However in finely porous media the negative pressure in the film sets up a hydrostatic pressure gradient causing water to flowto the ice surface. Here it freezes, forming an ice lens of macroscopic size and leading to frost heave (Wettlaufer, 1999; for a contrary view, see Torrance and Schelekens, 2006). However little frost heave is seen in the peaty, coarsely porous soils we are dealing with here. We attribute this absence of frost heave to cavitation in the soilwater under tension in these peats, a cavitation facilitated by degassing as thewater freezes and by plentiful ice nucleation centres in the soil. For this reason, we suggest that tension in water in this soil is likely confined to the pre-melting layers themselves, rather than being transmitted, as in finely porous media, to surrounding water. It is not thought relevant to the question of survival and growth of micron-scale organisms.

\subsection{The osmotic depression of the freezing point}

This is the incidental result of solutes in soil water lowering its chemical potential and hence its freezing point. As the soil water freezes, solutes are excluded from the ice, which is a poor solvent, increasing the solute concentration in the remaining liquid water and reducing its freezing point. At a given 
temperature freezing will continue until the chemical potential of the soil water is just that required to equal that of ice at the same temperature (inwater potential units), so that it falls at about 1.1 MPa per

$\mathrm{C}$ fall in temperature.1 The solute concentration in unfrozen water at soil temperatures just below $0 \mathrm{C}$ is likely to lead to only a small increase in the local solute concentration, as water steadily freezes at the interface of the ice, excluding its solutes (St€ahli and Stadler, 1997; Watanabe et al., 2001). In contrast, when the soil temperature falls to around $10 \mathrm{C}$, the solute concentration in caches of unfrozen water may approach saturation (St€ahli and Stadler, 1997) and lead to very low water potentials of the order of $10 \mathrm{MPa}$. This fall in osmotic potential as the soilwater freezes is expected to directly affect microorganisms, withdrawing water from the cell contents, first reducing the turgor pressure and then the cell volume, so increasing internal solute concentrations (Csonka, 1989; Wolfe and Bryant, 1992, 1999, 2008). Internal concentrations of compatible solutes will also rise in microorganisms due to synthesis and uptake (Csonka, 1989; Csonka and Hanson, 1991). The effects of these physical changes on the soil microbial flora will be discussed in greater detail below.

\section{Snow and ice melt, and soil thaw}

At the winter-spring transition these physical changes do not just happen in reverse order. With increasing soil temperatures, the solute concentration in the caches of unfrozen water falls, brought about by the inflow of snow-melt water along interconnected channels in the surface ice and soil, and the melting of the soil ice. The soil temperature rises very slowly just below the freezing point, resulting in quasi iso-thermal conditions. When all the ice has melted the temperature leaves this iso-thermal state, the so-called "zero-curtain envelope" (Muller, 1947; Washburn, 1973), and rises above 0 C.

In late February and March, increases in the amount of solar radiation begin to impact on landscape surfaces resulting in considerable sublimation. Snow cover and depth may vary considerably across the landscape, depending on previous amounts of precipitation, wind speeds, topography, and vegetative cover (Hinzman et al., 1996). Both snow and ice allow some transmission of short-wave radiation, although some absorption occurs within the volume of snow and ice (Oke, 1987).

Radiative heat transfer dominates over heat conduction in the upper $50 \mathrm{~cm}$ of snow and the upper $5 \mathrm{~m}$ of ice because short-wave radiation is transmitted much more readily than long-wave radiation in these media (Oke, 1987). Although fresh snow has a high albedo, the accumulation of material on the surface, such as soot, plant material, and dust, appreciably lowers the albedo. In addition, in late afternoon films of free water are often present on snow or ice surfaces that reduce the albedo close to that of water (c. 0.1) (Oke, 1987). Thus, the surface properties of snow and ice determine the transmission or reflexion of incoming short-wave radiation.

Living vegetation and dead shoots buried in ice and snow absorb transmitted radiation, becoming an anomalous thermal feature compared with surrounding snow and ice because of their different albedo values, leading to the melting of snow and the establishment of drain holes surrounding plant tissues (Kane and Stein, 1983). There is increasing build-up of unfrozen water beneath snow as melt proceeds. Snow has a high pore capacity and there are numerous dendritic channels though which unfrozen water 
drains into frozen ground beneath surface ice (see Kane and Stein,1983 and Marsh and Woo, 1984 for a detailed description). Once the finger wetting front (Marsh and Woo, 1984) reaches the snow-soil interface, water may infiltrate the soil or forma saturated layer at the interface which freezes due to the low soil surface temperature (Woo and Heron, 1981). A significant portion of the latent heat released upon this freezing raises the temperature of the ground (Marsh and Woo, 1984). Some of the water that infiltrates into the soil will be refrozen. With increasing soil temperatures in April and May in the range of $10 \mathrm{C}$ to $3 \mathrm{C}$, the water potential of this unfrozen layer is less negative as free water becomes available and the solute concentration is diluted. Under the increased radiation load in the daytime and the presence of free water, soil ice melts and more water penetrates the less frozen ground through channels and cracks that have developed in the surface ice. The anomalous thermal properties of living or dead plant tissues embedded in the ice, which have a different albedo from that of ice, also influence the penetration of water into the frozen ground as described above for snow. At a microsite scale this means that some areas will be inundated with fresh water while other microsites remain frozen for a longer time, with differing consequences for soil microorganisms inhabiting different microsites. Respiration of living below-ground tissues may contribute locally to heat transfer resulting in the development and a widening of water channels through the ice.

As indicated earlier, the pore space of these peaty soils is high (c.80\% by volume or more) and they are water-saturated for most of the snow-free season(Luxmoore,1981; Careyet al., 2007).During the early stages of the winter-spring transition, the temperature in the upper $15 \mathrm{~cm}$ of soil rises rapidly towards 0

C. This is thought to be a consequence of non-conductive heat transfer within the mat due to solar radiation (Hinkel and Outcalt, 1994; Romanovsky and Osterkamp, 2000; Kane et al., 2001). The steepness of the rise depends on the thermal properties of the substratum and the ability of solar radiation to penetrate the snow and ice leading to an increase in the amount of unfrozen water in the bulk frozen ground. The temperature rise leads to the zero curtain envelope and iso-thermal conditions (Muller,1947; Washburn, 1973; Hinkel et al., 2001). The temperature in the upper layer of the soil is within a few degrees of the freezing point of water and shows a steady slow climb to $0 \mathrm{C}$ over 10 days to two weeks.

\section{Seasonal patterns of microbial biomass: cold-adapted microbes, and their physiological responses to cold}

During the late fall, when plants have senesced and there is a ready supply of substrate from fresh plant litter (including roots), the microbial flora continues to be active, in some cases resulting in higher microbial biomass in winter than in other seasons (Brooks et al.,1998; Lipson et al., 2000; Nemergut et al., 2005; Edwards et al., 2006). Snow cover insulates the ground, moderating soil temperatures relative to air temperatures, and constraining minimum soil temperatures (Groffman et al., 2001; Buckeridge and Grogan, 2008). Where snow depth reaches at least $50 \mathrm{~cm}$, air and soil temperatures become decoupled (Larsen et al., 2007) so that soil temperatures can remain at - $10{ }^{\circ} \mathrm{C}$ or higher despite fluctuating and much colder air temperatures. At these soil temperatures, as discussed above, some 
unfrozen water occurs in the soil (Romanovsky and Osterkamp, 2000; Price and Sowers, 2004) in which microorganisms are present (Coxson and Parkinson,1987; Rivkina et al., 2000; Mikan et al., 2002).

Microbial activity declines substantially as soil temperatures in the active layer approach $10 \mathrm{C}$ (Mikan et al., 2002), as occurs in mid-winter in Arctic sites. Evidence from Arctic soils during the winter (Edwards et al., 2006) suggests that, as in alpine sites (Brooks et al., 1998; Lipson et al., 2000; Schmidt and Lipson, 2004), peak microbial biomass tends to occur in the latter half of the winter season. In spite of the high biomass, the turnover rate of microbial nitrogen is extremely slow in late winter (Buckeridge and Jefferies, 2007). Where microbial biomass is known to be high in late winter, levels decline markedly during the winter-spring transition (Lipson et al., 2000; Edwards et al., 2006; Larsen et al., 2007). For example, the decline in biomass from peak values in Arctic wet sedge meadows at Churchill, Manitoba appears to start in most years just prior or at the onset of the zero-curtain period when iso-thermal conditions prevail (Fig. 1, redrawn from Edwards et al., 2006). By the time soil temperatures rise above 0 $C$ at the end of the zero-curtain period, microbial biomass values are very low (Fig. 1). This decline in biomass may be accompanied by broad changes in the microbial community composition, as has been shown in Alpine sites where fungi are more dominant in winter and bacteria are more active in summer (Lipson et al., 2002; Schadt et al., 2003); however, the same was not observed in Arctic tundra soils where seasonal shifts occurred only at much finer taxonomic scales (Wallenstein et al., 2007).

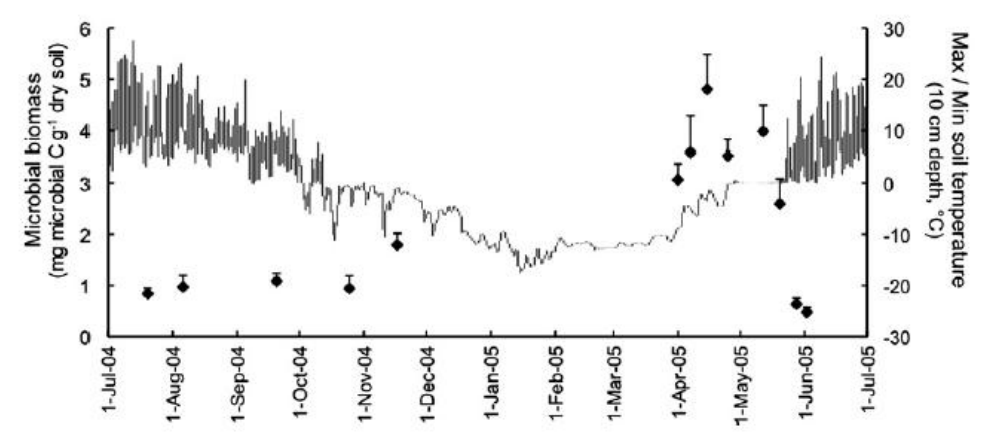

Fig. 1. Seasonal patterns of microbial biomass (values shown as solid diamonds \pm S.E., $n=6$ ) and daily maximum and minimum soil temperatures in the active layer (10 $\mathrm{cm}$ depth; solid line) in a wet sedge meadow on the Churchill Peninsula, Manitoba, Canada between July, 2004 and June 2005. The zero-curtain envelope is from 25 April to 20 May during which time iso-thermal conditions prevail and the temperature is just below $0^{\circ} \mathrm{C}$.

Quantifying and characterizing the microbes that exist in frozen soils is difficult using traditional techniques that may require soil to be thawed or incubated above $0 \quad \mathrm{C}$. Determining viability of cells (i.e. those that are capable of living but may be dormant) and whether cells are actively metabolizing and even growing are significant challenges (Gilichinsky, 1995). In an Arctic tundra birch hummock site, Buckeridge and Grogan (2008) estimated total bacterial cell numbers in the active layer at the end of winter to be approximately $5 * 10^{9}$ cell g ${ }^{-1}$ dry soil, roughly consistent with both alpine sites (Lipson et al., 2002) and a little higher than estimates from permafrost soils (up to 108 cells g 1; Rivkina et al., 1998). In both the Arctic and the alpine case, fungal estimates of biomass were much higher than those for bacteria, with wintertime fungal:bacterial ratios of 4.3 and 1.6 respectively (Lipson et al., 2002; Buckeridge and Grogan, 2008). Measuring culturable bacteria from Arctic tundra soils, Vishnivetskaya et al. (2000) estimated roughly 105 cells g 1 wet sediment, with estimates from some permafrost samples being similar. Viable organisms identified from permafrost have been found to be predominantly 
aerobic and anaerobic bacteria, but cyanobacteria, algae, yeasts, filamentous fungi, and Archaea have also been isolated from these perennially frozen soils (Gilichinsky et al., 1995; Rivkina et al., 2004). Based on the temperature classification of Morita (1975), most organisms are believed to be psychrotrophic (pyschrotolerant), capable of growing below 0 C but also above 20 C (Gounot, 1986; Gilichinsky, 1995; Gilichinsky et al., 2007; Rivkina et al., 2004; Steven et al., 2006). There is evidence of microbial growth (basidiomycetous yeasts, ascomycetous fungi, and bacteria represented by Pseudomonas, Arthrobacter and Polaromonas) at temperatures between $18 \mathrm{C}$ and $35 \mathrm{C}$ (Panikov and Sizova, 2007), and microbial respiration has been measured down to 40 C (Panikov et al., 2006). In order to survive conditions of high solute concentration organisms may also be halotolerant, such as Psychrobacter and Exiguobacterium isolates from Siberian permafrost that displayed metabolic activity at 5 osMolar (2.79 M NaCl i.e. $11 \mathrm{MPa}$ ) (Ponder et al., 2008).

At the onset of winter, the microbial flora must contend with both decreasing temperatures, and increasing solute concentration of the soil water as solutes are excluded from developing ice in the soils e hence the organisms must be both psychrotolerant and halotolerant to survive (Franks et al., 1990; Deming, 2002). Several physiological adjustments take place for cells to survive cold temperatures, including increasing enzymatic activities, membrane bilayer changes that maintain membrane fluidity and enable solute transport, and changes in gene expression known collectively as the cold shock response (Franks et al., 1990; Beales, 2004). Physiological responses to desiccation stress under cold conditions mirror those required for survival during other situations of cellular drought in which the extracellular environment is characterized by high osmolarity, or low water potential (Csonka, 1989; Potts, 1994; Schimel et al., 2007). In general, microorganisms are able to survive cold-induced dehydration and resist intracellular ice formation by supercooling and/or reduction of freezing point by the production and uptake of compatible organic solutes and changes in the composition of membranes (Franks et al., 1990; Wolfe and Bryant, 1992, 2008; Beales, 2004).

As ice forms in the bulk soil and extracellular osmolarity is increased, cellular turgor pressure may be lost temporarily, but can be regained through osmoregulation: an increase in intracellular osmotic concentrations through the withdrawal of water and the build-up of compatible solutes. Compatible solutes allow for the continued functioning of cellular enzymes and can be synthesized within the cell (such as glutamate, proline, glutathione, trehalose, and $\mathrm{Kp}$ ) or can be taken up from the extracellular environment (glycine betaine and proline) (Csonka, 1989; Csonka and Hanson, 1991; Beales, 2004; Schimel et al., 2007). In addition, a low external osmotic potential can cause a large reduction in the aqueous volume of the cell and in the area of the plasma membrane. The extent of osmotic contraction of cells depends upon the cooling rate and the prevailing temperatures (Mazur, 1963). The integrity of the plasma membrane and endoplasmic membranes is critical in the adjustment of cells and involves changes in the lipid composition of the plasmamembrane, as the cells adjust to these low osmotic potentials (Uemura et al., 1995). Phospholipids are incorporated into the existing membrane when an increase in area is required (Wolfe and Steponkus, 1983); however, cells may still succumb upon osmotic expansion because of the loss of ability of cold-tolerant, dehydrated cells to alter their membrane composition rapidly. In bacterial membranes there is an increase in membrane cis-unsaturated lipid fatty acid composition in response to sub-zero temperatures (Russell, 2007). The modification of the 
lipid composition of the membranes maintains the fluidity of the lipid bilayer by inducing a kink in the acetyl chains that reduce contact between adjacent chains and alter the organization of the membrane bilayer (Feller, 2006; Russell, 2007). Some, but not all, psychrotolerant microorganisms have the ability to convert cis- to trans-unsaturated fatty acids in less than $2 \mathrm{~h}$ when an increase in free water occurs and temperatures rise. However, the response is not reversible during freeze-thaw cycles (Okuyama et al., 1997; Russell, 2007). Desiccation-induced changes in membrane lipids further to those caused by low-temperature stress include an increase in anionic phospholipids in the membrane bilayer relative to neutral, zwitterionic lipids (Beales, 2004).

Intact semi-permeable membranes are essential for maintaining the different solute composition of intra-compared with the extracellular solutions, and helping to prevent intracellular ice nucleation. However, at the end of winter, the input of melt water in ice channels may lead to a rapid increase in the external osmotic potential (see below). This will cause a rupture of cell membranes and rapid cell death if the plasma membrane cannot expand quickly enough to accommodate the osmotic excursion, or if the cell cannot gracefully release its accumulated compatible solutes. The release of intracellular solutes occurs under situations of acute hypo-osmotic stress by way of mechano-sensitive (MS) channels in the membrane, which are activated when a sudden drop in extracellular osmotic concentration is detected (Morbach and Kramer, 2002). However, cell rupture may occur if the increase in osmotic potential is too great and too rapid for MS channels to compensate for, as can happen when microorganisms in desiccated soil experience rewetting (Morbach and Kr€amer, 2002; Schimel et al., 2007). Membranes have a limited ability to re-expand rapidly, because the rate of expansion is determined by the rate at which the cell can add material to the membrane. Membranes cannot stretch appreciably and can support a tension of only several mN m 1 without rupturing (Wolfe and Bryant, 1992, 2008). It has long been known that cells of some plant species have a limited ability to re-expand osmotically (Levitt and Scarth, 1936). The use of plant protoplasts has shown that when they are placed in hypertonic solutions, they become spherical with a reduction in surface area. The plasma membrane has a small resting-state surface tension which is less than $1 \mathrm{mN} \mathrm{m} 1$. Upon dilution of the external solution, a large influx of water into the cell occurs, but the membrane is capable of expansion of only a few percent without rupture (Wolfe and Bryant, 2008). When the membrane reaches a tension of $4 \mathrm{e} 6$ $\mathrm{mN} \mathrm{m} 1$ lysis will occur (Dowgert and Steponkus, 1984).

\section{Possible causes of microbial decline during the winter-spring transition}

Various hypotheses have been suggested to explain the decline of microbial biomass in many seasonally frozen soils during the winter-spring transition, including starvation, temperature rise, and freeze-thaw cycles. We suggest that cell rupture as a consequence of hypo-osmotic shock should also be considered as a potential contributor to the observed microbial decline.

Lipson et al. (2000) argue that the decline in microbial biomass at the winter-spring transition is at least, in part, caused by a depletion of labile $C$ substrates produced as a result of decomposition in fall and during the winter. Indeed, there is experimental evidence that provides some support for this 
hypothesis (Brooks et al., 2004; Buckeridge and Grogan, 2008) but in some situations the addition of carbon has not prevented the microbial decline from occurring (Edwards, unpublished observations). The lack of resources may contribute to the microbial decline, but this is likely not the only stressor that results in loss of biomass at the onset of spring.

Increasing temperatures in spring have also been invoked as a potentially lethal stress on any microbes that require cold temperatures (psychrophiles) (Lipson et al., 2000). Currently, the proportion of winter microbes that are psychrophiles and might be vulnerable to spring and summer soil temperatures is unknown. Studies of the microbial communities of permafrost soils indicate that organisms are predominantly psychrotrophic (Rivkina et al., 2004). However, the isolation of microorganisms from permafrost sediments is extremely difficult and true psychrophiles are rarely isolated (Vishnivetskaya et al., 2000). Because most extractions and isolations take place at temperatures above $0 \mathrm{C}$, psychrophiles may not survive and consequently are underrepresented in the isolates. Therefore, the possibility that a rise of biomass in winter followed by a decline at the end of winter could be caused by a bloom of psychrophiles adapted to soil temperatures below $0{ }^{\circ} \mathrm{C}$ cannot be ruled out.

Freeze-thaw cycles have also been implicated in the death of soil microbes during the winter-spring transition, but their effects on soil microbes remain unclear, as experimental studies have produced mixed results (Henry, 2007). In some experimental studies a single freeze-thaw event killed up to $50 \%$ of the viable soil microbes (Soulides and Allison, 1961; Skogland et al., 1988; DeLuca et al., 1992). However, many experimental freeze-thaw studies fail to properly simulate natural freezeethaw cycles, exposing microbes to temperature fluctuations that were much more severe than would typically be encountered in nature (Henry, 2007). Regardless of the potential effects of freeze-thaw cycles on the late-winter microbial population, occurrences of refreezing events in water-saturated soils below $10 \mathrm{~cm}$ depth are believed to be relatively uncommon due to the insulation of wet soils from fluctuating air temperatures. Soil refreezing can occur on occasions but by this stage much of the microbial biomass has already been lost prior to soil temperatures rising above $0{ }^{\circ} \mathrm{C}$.

As discussed earlier, there is a dendritic network of channels and cracks in surface ice that continue into the frozen ground beneath the ice. These are likely to be more evident at the end of winter when stresses and strains in old ice promote channel formation and the widening of the conduits that may be supplemented by additional channels that establish around shoots of wetland plants. The net effect of melt water release from snow and above surface ground ice is that there is a downward movement of water of low solute content into the soil during the zero-curtain envelope period when the unfrozen water content of the soil rises and iso-thermal conditions prevail. At this time the rapid movement of melt water into soil via ice channels may lead to membrane rupture in the manner described above, if dehydrated cells are unable to adjust to the abrupt rise in soil osmotic potential. For cells that do survive, the loss of significant amounts of intracellular solutes may also reduce their biomass. Both cell rupture and loss of internal solutes, driven by hydrologic and osmotic changes in the soil, are likely contributors to the loss of microbial biomass at the onset of spring.

Both alpine and Arctic environments are very heterogeneous with respect to vegetation types and soil conditions and the paucity of studies on seasonal changes, especially in relation to intensive spatial- 
temporal sampling and realistic experimental conditions suggests caution in attributing the microbial decline to a single cause. In this connection it is notable that on rewetting of desiccated soil, there is a loss ranging up to 50\% of the biomass (Schimel et al., 2007; but see Fierer and Schimel, 2003 for a different result). This loss is attributed to dumping of compatible solutes without cell death (Halverson et al., 2000). The close analogy between loss of water due to desiccation and that due to freezing means that we should consider cellular responses to rapid osmotic shifts to be at least partially responsible for the microbial biomass decline during the winter-spring transition.

\section{Conclusion and implications}

In summary, a factor in a decline in microbial biomass at the winter-spring transition may be the deleterious consequences of an abrupt change in osmotic potential before the soil temperature exceeds 0 C. Loss of psychrophilic organisms as the temperature rises may also contribute to the decline in microbial biomass in cold soils, as may a reduction in substrate availability, and the potentially disruptive effects of freeze-thaw cycles. The relative contributions of these different causes can be expected to vary across sites and years, and indeed may also vary at the microsite scale. If this is correct, a decrease in the activity of microorganisms capable of growing at sub-zero temperatures in northern soils may be anticipated as the number of winter warming events increases. Climate change is expected to cause the loss of an extended period where the soil temperature is sub-zero (IPCC, 2007). In addition, any decline in plant primary production associated with climate change, such as increased summer drought, may be expected to limit the availability of substrates in soils in the following autumn and winter for microbial growth. The steep decline in microbial biomass in late winter is frequently followed by a pulse of soluble nutrients, such as nitrogen and phosphorus, resulting from the lysis of cells. This release of nutrients represents the largest single annual input of available nitrogen into these cold soils and provides a significant source of this element to plants for summer growth (Jaeger et al.,1999; Lipson et al., 1999, 2000). It is known that some roots can take up $\mathrm{N}$ under the snowpack in Arctic sites (Bilbrough et al., 2000; Edwards, unpublished observations). However, reduced microbial growth in winter associated with soil temperatures reaching or exceeding $0 \mathrm{C}$ could result in a decline in the nutrient pulse. This will reduce the quantity of nutrients for spring plant growth and adversely affect production at higher trophic levels in these northern environments.

\section{Acknowledgements}

Two of us (R.L.J. and K.A.E.) gratefully acknowledge financial support from NSERC and IPY-NSERC (Arctic WOLVES I), the Department of Indian and Northern Affairs, Canada, and the Churchill Northern Studies Centre. The authors thank many colleagues for sharing observations and insights on these topics, and several anonymous reviewers for sound advice that greatly helped the manuscript. 


\section{References}

Beales, N., 2004. Adaptation of microorganisms to cold temperatures, weak acid preservatives, low pH, and osmotic stress: a review. Comprehensive Reviews in Food Science and Food Safety 3, 1e20.

Bilbrough, C., Welker, J., Bowman, W.D., 2000. Early spring nitrogen uptake by snow- covered plants: a comparison of arctic and alpine plant function under the snowpack. Arctic, Antarctic and Alpine Research 32, 404e411.

Brooks, P.D., Williams, M.W., Schmidt, S.K., 1998. Inorganic nitrogen and microbial biomass dynamics before and during spring snowmelt. Biogeochemistry 43,1e15.

Brooks, P.D., McKnight, D., Elder, K., 2004. Carbon limitation of soil respiration under winter snowpacks: potentia feedbacks between growing season and winter carbon fluxes. Global Change Biology 11, 231e238.

Buckeridge, K.M., Grogan, P., 2008. Deepened snow alters soil microbial nutrient limitations in arctic birch hummock tundra. Applied Soil Ecology 39, 210e222. Buckeridge, K.M., Jefferies, R.L., 2007. Vegetation loss alters soil nitrogen dynamics in an Arctic salt marsh. Journal of Ecology 95, $283 e 293$.

Carey, S.K., Quinton, W.L., Goeller, N.T., 2007. Field and laboratory estimates of pore size properties and hydraulic characteristics for subarctic organic soils. Hydrological Processes 21, 2560e2571.

Carey, S.K., Pomeroy, J.W., 2009. Progress in Canadian snow and frozen ground hydrology, 2003e2007. Canadian Water Resources Journal 34, 127e138.

Carey, S.K., Quinton, W.L., 2005. Evaluation of runoff generation during summer using hydrometric, stable isotope and hydrochemical methods in a discontinuous permafrost environment. Hydrological Processes 19, $95 \mathrm{e} 114$.

Carey, S.K., Woo, M.-K., 2001. Slope runoff processes and flow generation in a subarctic, subalpine environment. Journal of Hydrology 253, 110e129.

Coxson, D.S., Parkinson, D., 1987. Winter respiratory activity in aspen woodland forest floor litter and soils. Soil Biology \& Biochemistry 19, 49e59. Csonka, L.N., 1989. Physiological and genetic responses of bacteria to osmotic stress. Microbiological Reviews 53, 121e147.

Csonka, L.N., Hanson, A.D., 1991. Prokaryotic osmoregulation: genetics and physiology. Annual Review of Microbiology 45, 569e606.

Dash, J.G., 1989. Thermomolecular pressure in surface melting: motivation for frost heave. Science 246, $1591 \mathrm{e} 1593$.

DeLuca, T.H., Keeney, D.R., McCarty, G.W., 1992. Effect of freezeethaw events on mineralization of soil nitrogen. Biology and Fertility of Soils 14, 116e120. Deming, J.W., 2002. Psychrophiles and polar regions. Current Opinions in Microbiology 5, 301e309.

Dowgert, M.F., Steponkus, P.L., 1984. Behavior of the plasma membrane of isolated protoplasts during a freezeethaw cycle. Plant Physiology 75, 1139e1151.

Dunn, C.H., Phillips, R.E., 1991. Macroporosity of a well-drained soil under no-till and conventional tillage. Soil Science Society of America Journal 55, 817e823.

Edwards, K.A., McCulloch, J., Kershaw, G.P., Jefferies, R.L., 2006. Soil microbial and nutrient dynamics in a wet Arctic sedge meadow in late winter and early spring. Soil Biology and Biochemistry 38, 2843e2851. 
Fahnestock, J.T., Jones, M.H., Brooks, P.D., Walker, D.A., Welker, J.M., 1998. Winter and early spring CO2 efflux from tundra communities of northern Alaska. Journal of Geophysical Research-Atmospheres 103, $29023 e 29027$.

Feller, G., 2006. Life at low temperatures: is disorder the driving force? Extemophiles 10, $211 \mathrm{e} 216$.

Fierer, N., Schimel, J.P., 2003. A proposed mechanism for the pulse in carbon dioxide production commonly observed following the rapid rewetting of a dry soil. Soil Science Society of America Journal 67, $798 \mathrm{e} 805$.

Franks, F., Mathias, S.F., Hatley, R.H.M., Baust, J.G., Hvidt, A., Chapman, D., Jaenicke, R., 1990.Water, temperature and life [and discussion]. Philosophical Transactions of the Royal Society of London Series B, Biological Sciences 326, 517e533.

Gilichinsky, D., 1995. Microbial life in permafrost: a historical review. Permafrost and Periglacial Processes 6, $243 e 250$.

Gilichinsky, D.A., Wilson, G.S., Friedmann, E.I., Mckay, D.P., Sletten, R.S., Rivkina, E.M., Vishnivetskaya, T.A., Erokhina, L.G., Ivanushkina, N.E., Kochkina, G.A., Shcherbakova, V.A., Soina, V.S., Spirina, E.V., Vorobyova, E.A., Fyodorow-Davydov, D.G., Hallet, B., Ozerskaya, S.M., Sorokovikov, V.A., Laurinavichyus, K.S., Shatilovich, A.V., Chanton, J.P., Ostroumov, V.E., Tiedje, J.M., 2007. Microbial populations in Antarctic permafrost: biodiversity, state, age, and implication for astrobiology. Astrobiology 7, 275e311. Gounot, A., 1986. Psychrophilic and psychotrophic microorganisms. Experimenta 42, 1192e1197.

Groffman, P.M., Driscoll, C.T., Fahey, T.J., Hardy, J.P., Fitzhugh, R.D., Tierney, G.L., 2001. Colder soils in a warmer world: a snow manipulation study in a northern hardwood forest ecosystem. Biogeochemistry 56, $135 e 150$.

Halverson, L.J., Jones, T.M., Firestone, M.K., 2000. Release of intracellular solutes by four soil bacteria exposed to dilution stress. Soil Science Society of America Journal 64, 1634e1637.

Henry, H.A.L., 2007. Soil freezeethaw cycle experiments: trends, methodological weaknesses and suggested improvements. Soil Biology \& Biochemistry 39, 977e986

Hinkel, K.M., Paetzold, F., Nelson, F.E., Bockheim, J.G., 2001. Patterns of soil temperature and moisture in the active layer and upper permafrost at Barrow, Alaska: 1993e1999. Global and Planetary Change 29, $293 e 309$.

Hinkel, K.M., Outcalt, S.I., 1994. Identification of heat-transfer processes during soil cooling, freezing, and thaw in central Alaska. Permafrost and Periglacial Processes 5, 217e235.

Hinzman, L.D., Kane, D.L., Benson, C.S., Everett, K.R., 1996. Energy balance and hydrological processes in an Arctic watershed. In: Reynolds, J.F., Tenhunen, J.D. (Eds.), Landscape Function and Disturbance in Arctic Tundra. Springer, New York, pp. 132e154.

IPCC, 2007. Climate change 2007. In: Parry, M., Canziani, O., Palutikof, J., van der Linden, P., Hanson, C. (Eds.), Impacts, Adaptation and Vulnerability. Cambridge University Press, Cambridge, U.K.

Jaeger, C.H., Monson, R.K., Fisk, M.C., Schmidt, S.K., 1999. Seasonal partitioning of nitrogen by plants and soil microorganisms in an alpine ecosystem. Ecology 80, 1883 e1891.

Kane, D.L., Hinkel, K.M., Goering, D.J., Hinzman, L.D., Outcalt, S.I., 2001. Nonconductive heat transfer associated with frozen soils. Global and Planetary Change 29, $275 \mathrm{e} 292$.

Kane, D.L., Stein, J., 1983. Water movement into seasonally frozen soils. Water Resources Research 19, $1547 e 1557$. 
Larsen, K.S., Grogan, P., Jonasson, S., Michelsen, A., 2007. Respiration and microbial dynamics in two subarctic ecosystems during winter and spring thaw: effects of increased snow depth. Arctic, Antarctic and Alpine Research 39, $268 \mathrm{e} 276$.

Levitt, J., Scarth, G.W., 1936. Frost hardening studies with living cells II. Permeability in relation to frost resistance and the seasonal cycle. Canadian Journal of Research: Section C Botanical Sciences 14, 285e305.

Lipson, D.A., Schmidt, S.K., Monson, R.K., 1999. Links between microbial population dynamics andnitrogen availability in an alpine ecosystem. Ecology 80,1623e1631.

Lipson, D.A., Schmidt, S.K., Monson, R.K., 2000. Carbon availability and temperature control the post snow- melt baseline in alpine soil microbial biomass. Soil Biology \& Biochemistry 32, 441e448.

Lipson, D.A., Schadt, C.W., Schmidt, S.K., 2002. Changes in soil microbial community structure and function in an alpine dry meadow following spring snow melt. Microbial Ecology 43, 307e314.

Luxmoore, R.J., 1981. Micro-, meso- and macroporosity of soil. Soil Science Society of America Journal 45, $671 \mathrm{e} 672$.

Marsh, P., Woo, M.-K., 1984. Wetting front advance and freezing of meltwater within a snow cover 1. Observations in the Canadian Arctic. Water Resources Research 20, 1853e1864.

Mazur, P., 1963. Kinetics of water loss from cells at subzero temperatures and the likelihood of intracellular freezing. Journal of General Physiology 47, 347e369. Mikan, C.J., Schimal, J.P., Doyle, A.P., 2002. Temperature controls of microbial respiration in arctic tundra soil above and below freezing. Soil Biology \& Biochemistry 34, 1785e1795.

Morbach, S., Kr€amer, R., 2002. Body shaping under water stress: osmosensing and osmoregulation of solute transport in bacteria. ChemBioChem 3, 384e397. Morita, R., 1975. Psychrophilic bacteria. Bacteriological Reviews 30, 144e167.

Muller, S.W., 1947. Permafrost or Permanently Frozen Ground and Related Engineering Problems. J.W. Edwards, Publisher, Ann Arbor, Michigan, USA.

Nemergut, D.R., Costello, E.K., Meyer, A.F., Pescador, M.Y., Weintraub, M.N., Schmidt, S.K., 2005. Structure and function of alpine and arctic soil microbial communities. Research in Microbiology 156, 775e784.

Oke, T.R., 1987. Boundary Layer Climates. Routledge, London.

Okuyama, H., Enari, D., Morita, N., 1997. Identification and characterization of 9- cishexadecenoic acid cis-trans isomerase from a psychrotolerant bacterium Pseudomonas sp. strain E-3. Proceedings of NIPR Symposium in Polar Biology: Microbiology 10, $153 \mathrm{e} 162$.

Panikov, N.S., Flanagan, P.W., Oechel, W.C., Mastepanov, M.A., Christensen, T.R., 2006. Microbial activity in soils frozen to below 39 C. Soil Biology and Biochemistry 38, 785e794.

Panikov, N.S., Sizova, M.V., 2007. Growth kinetics of microorganisms isolated from Alaskan soil and permafrost in solid media frozen down to 35 C. FEMS Microbial Ecology 59, 500e512.

Passioura, J.B., 1980. The meaning of matric potential. Journal of Experimental Botany 31, 1161e1169.

Ponder, M., Thomasshow, M.F., Tiedje, J.M., 2008. Metabolic activity of Siberian permafrost isolates, Psychrobacter arcticus and Exiguobacterium sibiricum, at low water activities. Extemophiles 12, $481 \mathrm{e} 490$.

Potts, M., 1994. Desiccation tolerance of prokaryotes. Microbiological Reviews 58, 755e805. 
Price, P.B., Sowers, T., 2004. Temperature dependence of metabolic rates for microbial growth, maintenance and survival. Proceedings of the National Academy of Sciences of the United States of America 101, $4631 \mathrm{e} 4636$.

Quinton, W.L., Gray, D.M., Marsh, P., 2000. Subsurface drainage from hummockcovered hill slopes in the Arctic tundra. Journal of Hydrology 237, 113e125.

Quinton, W.L., Marsh, P., 1999. A conceptual framework for runoff generation in a permafrost environment. Hydrological Processes 13, 2563e2581.

Rempel, A.W., Wettlaufer, J.S., Worsted, M.G., 2004. Premelting dynamics in a continuum model of frost heave. Journal of Fluid Mechanics 498, 227e244.

Rivkina, E., Gilichinsky, D., Wagener, S., Tiedje, J., McGrath, J., 1998. Biogeochemical activity of anaerobic microorganisms from buried permafrost sediments. Journal of Geomicrobiology 15, 187e193.

Rivkina, E.M., Friedmann, E.I., McKay, C.P., Gilichinsky, D.A., 2000. Metabolic activity of permafrost bacteria below freezing point. Applied and Environmental Microbiology 66, 3230e3233.

Rivkina, E., Laurinavichius, K., McGrath, J., Tiedje, J., Shcherbakova, V., Gilichinsky, D., 2004. Microbial life in permafrost. Advances in Space Research 33, 1215e1221.

Romanovsky, V., Osterkamp, T., 2000. Effects of unfrozen water on heat and mass transport processes in the active layer of permafrost. Permafrost and Periglacial Processes 11, $219 \mathrm{e} 239$. 